\title{
Estimating Seasonal Movements of Chinook Salmon in Lake Huron from Efficiency Analysis of Coded Wire Tag Recoveries in Recreational Fisheries
}

\author{
Sara A. Adlerstein* \\ School of Natural Resources and Environment, University of Michigan, \\ 3010 Dana Building, Ann Arbor, Michigan. 48109-1115, USA
}

EDWARD S. RUTHERFORD

School of Natural Resources and Environment, Institute for Fisheries Research, University of Michigan, 218 Museum Annex Building, 1109 North University Avenue, Ann Arbor, Michigan 48109-1084, USA

\author{
David Clapp and John A. Clevenger \\ Michigan Department of Natural Resources, Charlevoix Fisheries Research Station, \\ Charlevoix, Michigan 49720, USA \\ JAMES E. JOHNSON \\ Michigan Department of Natural Resources, Alpena Fisheries Research Station, \\ Alpena, 49707 Michigan, USA
}

\begin{abstract}
The decline of hatchery-reared Chinook salmon Oncorhynchus tshawytscha stocks in Lakes Huron and Michigan during the 1980s prompted mass-tagging programs to investigate reproduction, poststocking survival, and movements. In Lake Huron, millions of smolts implanted with coded wire tags (CWTs) were released in Michigan waters and recovered from charter and noncharter fisheries, surveys, and weirs. Using generalized linear models (GLMs), we investigated Chinook salmon seasonal movements based on the spatial and temporal distributions of recoveries by fishing trips in U.S. recreational fisheries and recovery efficiency. We used models incorporating area, month, year, and recovery source; creel-clerk and "headhunter" (CWT collection specialist) samples; and charter captain reports. We implemented models for recoveries regardless of release area and from one particular area. All model predictors and interactions between month and area were significant. The variation in recovery levels among recovery sources was larger than temporal or spatial variation. Headhunters were 7 times more efficient than captains in recovering CWTs from charter-boat catch and 11 times more efficient than clerks in recovering CWTs from non-charter-boat catch; this was due to the higher catches experienced in charter than in noncharter trips and to different recovery program goals. The spatial and temporal distribution of GLM-standardized recovery levels suggested that Chinook salmon released along the western coast of Lake Huron moved near shore during early spring and north during summer, returning mostly to nearby stocking areas in summer and fall. To complement our GLM analysis, we evaluated the distributions of CWT salmon released and recovered in U.S. and Canadian waters by all sources. Data supported previous conclusions on longitudinal movements and indicated that in spring fish moved from eastern locations to near shore in western Lake Huron then back to overwinter locations in autumn. These movement patterns coincided with seasonal prey species concentrations and favorable temperatures. The implications of our results for salmon fisheries management and the design of future tagging studies are discussed.
\end{abstract}

Chinook salmon Oncorhynchus tshawytscha were introduced to the Great Lakes in 1967 to help control exotic forage fishes, particularly alewife Alosa pseudoharengus and rainbow smelt Osmerus mordax, and to create a sport fishery (Tody and Tanner 1966). From their introduction until the mid-1980s, Chinook salmon abundance fluctuated in synchrony with stocking

\section{* Corresponding author: adlerste@umich.edu}

Received August 10, 2006; accepted January 8, 2007 Published online June 28, 2007 levels, but in recent years abundance trends could not be explained by stocking levels alone (Whelan and Johnson 2004). In Lake Huron, annual stocking levels rose through the 1980s but were frozen after 1986 at approximately 4 million smolts following significant declines in abundance experienced in Lake Michigan (Whelan and Johnson 2004). In 1987, U.S. state resource agencies initiated a mass-marking program in Lakes Huron and Michigan to estimate Chinook salmon natural reproduction and poststocking survival and to track fish movements. Since then, about 9 
TABLE 1.-Number of Chinook salmon marked with coded wire tags (CWTs) and released by statistical district (MH1 to MH6) in Michigan waters of Lake Huron and total stocked from 1991 to 2000 (Great Lakes Fishery Commission 2006).

\begin{tabular}{|c|c|c|c|c|c|c|c|c|c|c|c|}
\hline \multirow[b]{2}{*}{ Year } & \multirow[b]{2}{*}{$\begin{array}{c}\text { MH1 } \\
\text { (Swan River) }\end{array}$} & \multicolumn{2}{|c|}{ MH3 } & \multicolumn{3}{|c|}{ MH4 } & \multirow[b]{2}{*}{$\begin{array}{c}\text { MH5 } \\
\text { (Harbor Beach) }\end{array}$} & \multicolumn{2}{|c|}{ MH6 } & \multirow[b]{2}{*}{$\begin{array}{l}\text { Number } \\
\text { CWTs }\end{array}$} & \multirow[b]{2}{*}{$\begin{array}{l}\text { Number } \\
\text { stocked }\end{array}$} \\
\hline & & $\begin{array}{c}\text { Mill } \\
\text { Creek }\end{array}$ & $\begin{array}{l}\text { AuSable } \\
\text { River }\end{array}$ & $\begin{array}{l}\text { Tawas } \\
\text { River }\end{array}$ & $\begin{array}{c}\text { Port } \\
\text { Austin }\end{array}$ & $\begin{array}{l}\text { AuGres } \\
\text { River }\end{array}$ & & $\begin{array}{c}\text { Port } \\
\text { Sanilac }\end{array}$ & $\begin{array}{l}\text { Lexington } \\
\text { Harbor }\end{array}$ & & \\
\hline 1991 & 215,617 & & 246,842 & & & & & & & 462,459 & $3,221,778$ \\
\hline 1992 & 208,052 & & 150,910 & & & & & & & 358,956 & $3,047,701$ \\
\hline 1993 & 200,100 & & 201,640 & & & & 100,000 & & & 501,740 & $3,287,234$ \\
\hline 1994 & 200,128 & & 200,130 & & & & 100,080 & & & 500,338 & $3,572,559$ \\
\hline 1995 & 102,000 & & 205,805 & & & & 207,943 & & & 515,748 & $3,829,157$ \\
\hline 1996 & 103,140 & & 196,356 & & & & 205,877 & & & 505,373 & $3,471,523$ \\
\hline 1997 & 102,354 & & 203,990 & & & & 206,242 & & & 512,586 & $3,287,581$ \\
\hline 1998 & 101,287 & & & 75,216 & 101,175 & & 204,143 & & & 481,821 & $3,311,052$ \\
\hline 1999 & 102,277 & & & 66,542 & 100,825 & & & & & 269,644 & $2,873,305$ \\
\hline 2000 & 101,731 & 104,339 & & 63,375 & 101,189 & 61,376 & & 81,175 & 81,625 & 594,810 & $3,051,486$ \\
\hline Total & $1,436,686$ & 104,339 & $1,405,673$ & 205,133 & 303,189 & 61,376 & $1,024,295$ & 81,175 & 81,625 & $4,703,481$ & $32,953,376$ \\
\hline
\end{tabular}

million smolts implanted with coded wire tags (CWT) were stocked, and recovery programs were set in place. In Lake Huron, more than 4 million CWT smolts were released between 1991 and 2000 (Table 1), mostly in the northern and central management areas on the west side of the lake (Figure 1; statistical districts MH1 and MH3). Marked fish constituted about $15 \%$ of the total number of Chinook salmon stocked per year (Table 1).

Information on movement is indispensable for the assessment and management of Chinook salmon in Lake Huron. The Chinook salmon is the top piscivore in the pelagic zone of the Lake Huron ecosystem and plays a key role in lake management by suppressing nuisance invasive species, particularly alewives (Kocik and Jones 1999). Chinook salmon also support a lucrative recreational fishery. Currently, the main basin of Lake Huron is treated as a single management unit for Chinook salmon, and reliable information on distribution and movements is needed to guide management decisions, particularly on stocking strategies (Johnson et al., in press). Although management does not explicitly account for movement, it is based on implicit views regarding mixing and movements of fish stocked in different locations. Furthermore, the validity of recreational fishery catch rates as an index of abundance for implementing population models requires an understanding of the overall area occupied by the stocks and temporal changes in local abundance. In this study, we investigate CWT recoveries of Chinook salmon to compare efficiencies of tag recovery programs and clarify seasonal and regional movement patterns for stock assessment.

Few studies have described the movements of Chinook salmon in the Great Lakes. In Lake Michigan, results indicated that seasonal movements of Chinook salmon were significant and in most cases were associated with changes in relative abundance of prey fish. Keller et al. (1990) reported changes in spatial distribution of Chinook salmon harvest in Lake Michigan that were indicative of high fish mobility. Elliott (1993) studied Chinook salmon diets and prey distributions and proposed that fish migrate in spring away from eastern waters of Lake Michigan and return in the fall following their prey. Benjamin and Bence (2003) reported on seasonal and annual trends in Chinook salmon recreational catch rates that showed substantial movement between eastern and western Lake Michigan. The Lake Huron Technical Committee and Lake Michigan Salmonid Working Group (2005) reported substantial net migration between Lakes Michigan and Huron based on CWT recoveries.

The objective of our study was to determine the feasibility of using CWT data from the mass-marking program started in 1991 to investigate the seasonal movement of Chinook salmon released in Lake Huron. Tag recovery programs were conducted from recreational and commercial charter fisheries, fisheriesindependent surveys, and weir harvests. We quantified spatial and temporal changes in distribution of marked fish along the west coast of Lake Huron based on data from the U.S. recreational fisheries and considered data from all sources of recovery to describe movement at larger spatial scales, including movement to Lake Michigan.

\section{Methods}

To study population distribution and migration based on recovery data, it is necessary to consider recovery effort (Hilborn 1990; Schmalz et al. 2002) and the efficiency of recovery sources, while to study direction of displacement it is sufficient to know the location of recoveries relative to where CWT fish were released. In Lake Huron, the recreational fisheries (including charter and noncharter operations) provided about $70 \%$ of the records available for CWT Chinook salmon recoveries; the rest were from fish recovered at 

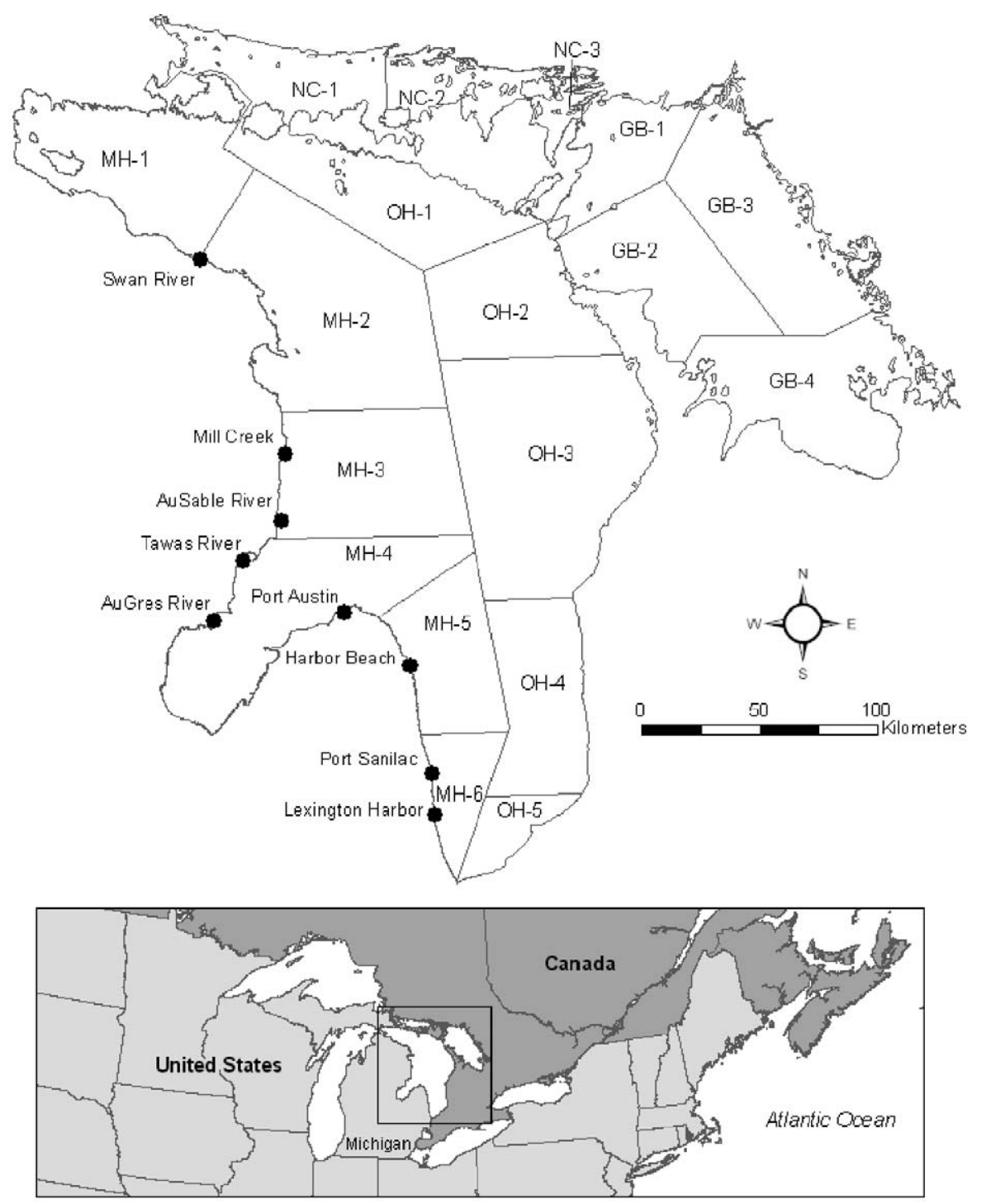

FIGURE 1.-Map of Lake Huron showing statistical districts and Chinook salmon release locations. Statistical districts MH-1 to MH-6 are located within U.S. waters, and others are located within Canadian waters.

weirs $(20 \%)$ and from fishery-independent assessments (10\%). Data from these CWT recovery sources cannot be combined to study population distribution, since effort is in different units. We used CWT data from U.S. recreational fisheries in Lake Huron that provide information of suitable temporal and spatial scales to investigate spatial and temporal distribution of recoveries, and we used data from all sources of recoveries in Lake Huron and Lake Michigan to describe displacement.

General approach.-We used a regression approach incorporating source of recovery as a predictor variable to develop spatially and temporally explicit abundance indices (Smith 1990) of Chinook salmon based on CWT recovery numbers and effort. We based the analysis on recoveries of fish released at stocking areas in U.S. waters (Figure 1) and recovered from the U.S. recreational fisheries. Using general linear models (GLMs), we modeled the number of CWT fish recovered by fishing trips (McCullagh and Nelder 1989). First, we modeled recoveries from fish released in all stocking locations in Michigan waters of Lake Huron, located in statistical districts MH1 to MH6 (Figure 1), without considering the specific area of 
release. Next, we modeled exclusively recovery data of fish released in MH3, where the largest numbers of marked fish were released. To complement the GLM analysis and expand the spatial distribution of CWT recoveries, we examined displacement using absolute recovery numbers of Chinook salmon released in Lake Huron and recovered in the release areas or elsewhere from all recovery sources.

Data sources.-We obtained CWT recovery data from the Michigan Department of Natural Resources (MDNR) CWT database and fishery catch and effort data for recreational fisheries from the MDNR creel, charter boat, and "headhunter" (i.e., technicians trained and assigned to recover CWTs) fishery databases. Data from CWT recoveries were obtained from fish tagged and released as smolts, as described in detail on the MDNR Web page (www.michigan.gov/dnr/ 0,1607,7-153-10364_10951_11301-97831-,00.html). Briefly, the tag, a piece of wire $0.25 \mathrm{~mm}$ in diameter with an engraved code, was injected into the fish's snout. Tag loss was assumed to be negligible (Hale and Gray 1998). During tagging, the adipose fins were removed to allow external recognition of fish bearing CWTs. After tagging, each lot of stocked fish was evaluated for CWT retention and fin clip quality. Fish recovered were inspected for fin clips, and snouts were removed from those with missing adipose fins and transferred to laboratories for further processing, tag removal, and code identification. The code number was read under a microscope, and the data were entered into the CWT database. The CWT recovery programs and processing of tags were carried out through collaborative efforts of the U.S. Geological Survey (USGS)Great Lakes Science Center, MDNR, ChippewaOttawa Resource Authority, Ontario Ministry of Natural Resources, the U.S. Fish and Wildlife Service, and various fishing groups. Creel and headhunter data were sampled during interviews that generally took place on shore at the completion of fishing trips. Charter-boat data were reported by captains.

Data from 3,366 CWT Chinook salmon were evaluated for the regression analysis of CWT recoveries by trip (Table 2). We did not include 3,997 additional records from CWT fish collected by volunteers because information was not recorded on the corresponding number of trips and the type of fishery from which fish were sampled. Data were collected from 1993, when the headhunter program started, until 2001, and from all management areas in U.S. waters of Lake Huron (Figure 1).

The fishery data used in the analysis consisted of catch information and effort by individual fishing trips and the date and site of interviews or fishing site. To pair CWT recoveries with the trips where tags were
TABLE 2.-Number of coded-wire-tagged Chinook salmon recovered in the 1993-2001 recreational fisheries in Michigan waters of Lake Huron, by month and recovery source, that were selected for the analysis. Sources of recovery are as follows: CBT = charter-boat catch reported by captains, CCK $=$ non-charter-boat catch sampled by creel clerks, HHB = charter-boat catch sampled by headhunters, and HHR = noncharter-boat catch sampled by headhunters.

\begin{tabular}{lrrrr}
\hline & \multicolumn{4}{c}{ Recovery source } \\
\cline { 2 - 5 } Month & CBT & CCK & HHB & HHR \\
\hline May & 33 & 36 & 11 & 259 \\
Jun & 49 & 100 & 15 & 185 \\
Jul & 108 & 225 & 35 & 574 \\
Aug & 124 & 330 & 34 & 509 \\
Sep & 109 & 332 & 2 & 126 \\
Oct & 10 & 94 & 0 & 6 \\
Total & 437 & 1,132 & 98 & 1,699 \\
\hline
\end{tabular}

recovered, we aggregated both the CWT and the effort data by month and statistical district of recovery; we also matched the number of CWT fish and the corresponding effort for each source of recovery. Since CWT recoveries were from fish caught by anglers and charter captains fishing on boats, we excluded effort for which the unit was not the fishing trip, such as fishing in piers, fishing on shore, and other modes of fishing (about $10 \%$ of the fishing records).

Data from 10,049 CWT fish released in U.S. waters and recovered in U.S. and Canadian waters, and from 389 CWT fish released in Canadian waters and recovered in U.S. waters, were used for the analysis of absolute number of CWT recoveries. These data were from all recovery sources, including modes of recreational fishing (volunteer returns) and nonrecreational sources that were not included in the regression analysis (above). Data from fish that were released and recovered in Canada were not available for analysis.

Data handling.-To estimate effective effort for recovering tags, we selected fishing trips that had a probability of catching Chinook salmon. The recreational fisheries in Lake Huron target multiple species, and the probability of catching Chinook salmon varies with the intended target. The main potential bias is that targeting some species could result in trips with zero probability of catching Chinook salmon, and thus variation in the proportion of such trips in time and space would cause fluctuation in recovery levels unrelated to fish density. From the species composition of the catch, we found that the presence of yellow perch Perca flavescens was an indicator of a near-zero probability of catching Chinook salmon, both in the charter and noncharter fisheries. Thus, for the analysis we used data from 130,000 trips that did not contain yellow perch conducted between 1993 and 2001 in statistical districts MH1 to MH6 (Table 
TABLE 3.-Number of effective recreational fishing trips from May to October 1993-2001 (charter and noncharter combined) for Chinook salmon by statistical district in Michigan waters of Lake Huron (excluding trips successful for yellow perch harvest).

\begin{tabular}{|c|c|c|c|c|c|c|c|}
\hline \multirow[b]{2}{*}{ Year } & \multicolumn{6}{|c|}{ Statistical district } & \multirow[b]{2}{*}{ Total } \\
\hline & MH1 & MH2 & MH3 & MH4 & MH5 & MH6 & \\
\hline 1993 & 1,818 & 2,416 & 2,452 & 3,049 & 2,612 & 1,523 & 13,870 \\
\hline 1994 & 1,980 & 2,332 & 2,124 & 2,099 & 1,401 & 1,479 & 11,415 \\
\hline 1995 & 2,900 & 2,840 & 2,960 & 2,025 & 1,997 & 1,605 & 14,327 \\
\hline 1996 & 2,722 & 3,348 & 2,738 & 2,367 & 2,248 & 1,489 & 14,912 \\
\hline 1997 & 2,280 & 3,200 & 3,582 & 1,811 & 2,374 & 1,803 & 15,050 \\
\hline 1998 & 1,769 & 2,745 & 3,593 & 2,552 & 2,422 & 1,244 & 14,325 \\
\hline 1999 & 3,915 & 2,178 & 2,989 & 2,384 & 2,307 & 1,057 & 14,830 \\
\hline 2000 & 4,579 & 1,379 & 3,471 & 1,811 & 1,939 & 935 & 14,114 \\
\hline 2001 & 4,879 & 1,119 & 3,305 & 1,851 & 2,094 & 1,564 & 14,812 \\
\hline Total & 26,842 & 21,557 & 27,214 & 19,949 & 13,394 & 12,699 & 127,655 \\
\hline
\end{tabular}

3). About $80 \%$ of those trips corresponded to noncharter-boat operations.

GLM analysis of recovery data by trips in the recreational fisheries.-To use CWT recovery data from the Lake Huron recreational fisheries and study the monthly distribution of Chinook salmon, it was necessary to investigate the differences in efficiency among the selected recovery sources in charter and noncharter operations. Tags recovered from charter operations were reported by charter-boat captains or sampled by headhunters, and creel clerks sampled tags from noncharter operations. In the GLMs, the recovery source was introduced as an explanatory factor with the four selected combinations as factor levels. The GLMs used in the analysis were of the form

$$
g\left(\mu_{y m d g}\right)=\alpha+\delta_{y}+\phi_{m}+\lambda_{d}+\tau_{g}
$$

where $\mu_{y m d g}$ is the expected tag recovery by trip, $\delta$ is the year, $\phi$ is the month, $\lambda$ is the statistical district, $\tau$ is the source of recovery, and $g$ is a link function. All covariates were introduced as factors. Models incorporated a binomial distribution to describe the probability of recovering a number of tagged fish given a number of trips. Each trip was treated as a Bernoulli trial, the expected catch of CWT fish constrained between 0 and 1 . Although multiple CWT recoveries are possible by fishing trip, $\mu$ was always very small because fishing regulations established daily bag limits of only three Chinook salmon and $10 \%$ of stocked fish were marked. We used the logit-link function $g(\mu)=\log _{e}[\mu /(1-\mu)]$, which is the canonical link for the binomial family. We performed analysis of deviance to test the significance of the explanatory variables. We tested first-order interactions between source of recovery and month, area, and year to investigate potential bias due to performance of personnel performing the CWT sampling. Also, we tested interactions between month and area to investigate whether seasonal variation was synchronized among areas. Higher-order interactions were not tested because they were of minor interest and data were limited. All tests were performed at the $95 \%$ confidence level. We ran model diagnostics to check validity of the model assumptions; including estimation of the model dispersion parameter to verify whether it was close to 1 as assumed for the binomial family. To run GLMs, we used the "glm function" contained in the S-Plus programming environment (Becker et al. 1988).

Analysis of absolute number of recoveries from all sources of recovery.-We extracted from the CWT database the absolute numbers of recoveries of CWT fish that were released in Canadian and U.S. waters of Lake Huron and recovered in the release areas and elsewhere. These data were collected from all sources of recoveries and could not be incorporated into the GLM for three reasons: there were different recovery programs in U.S. and Canadian waters, data to estimate recovery effort were missing, and fishing effort did not correspond to trips.

\section{Results}

GLM of Marked Fish Released in MHI to MH6 and Recovered from Recreational Fisheries

The main effects model explained about $50 \%$ of the variability in CWT recoveries per trip and incorporated

TABLE 4.-Analysis of deviance for main effects in a generalized linear model of tag recovery rates for Chinook salmon in recreational fisheries of Michigan waters of Lake Huron. Data are for May-October 1993-2001 and statistical districts MH1-MH6.

\begin{tabular}{lrrrr}
\hline \multicolumn{1}{c}{ Term } & df & Deviance & $\begin{array}{l}\text { Residual } \\
\text { deviance }\end{array}$ & $P(\chi)$ \\
\hline Null & 898 & 6,341 & & \\
Source of recovery & 3 & 1,732 & 4,608 & $<0.0001$ \\
Year & 8 & 764 & 3,843 & $<0.0001$ \\
Statistical district & 5 & 235 & 3,608 & $<0.0001$ \\
Month & 5 & 242 & 3,366 & $<0.0001$ \\
\hline
\end{tabular}



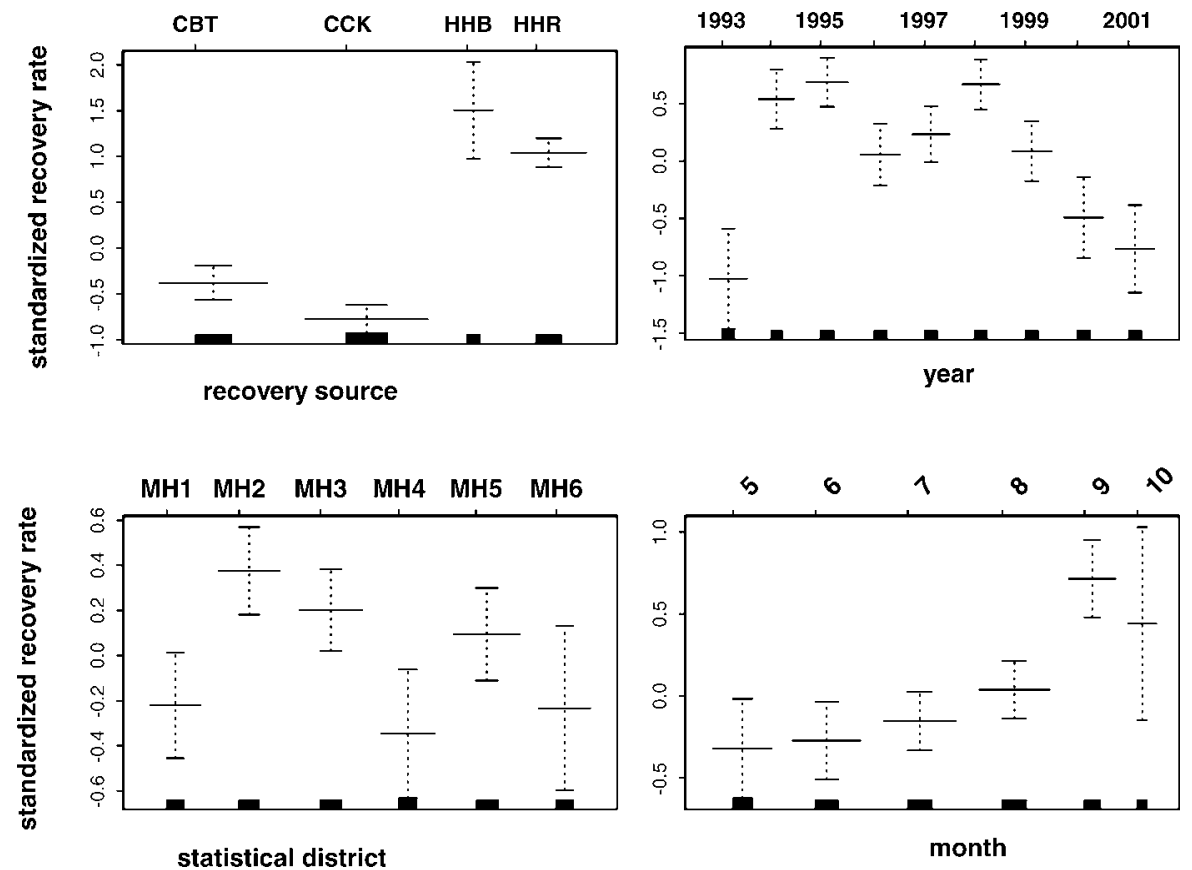

FIGURE 2.- Main effects from a generalized linear model of recovery rates of coded-wire-tagged Chinook salmon released in U.S. waters of Lake Huron from 1993 to 2000. Sources of recovery are as follows: CBT = charter-boat catch reported by captains, $\mathrm{CCK}=$ non-charter-boat catch sampled by creel clerks, HHB = charter-boat catch sampled by headhunters, and HHR = non-charter-boat catch sampled by headhunters. The scales of the $y$-axes are standardized so that the mean is centered at 0 in the logit-link scale. The $x$-axes show the levels of each variable in the model and a rug plot or sequence of vertical lines that mark the observed number of trips from which coded wire tags were recovered $(2,644-77,083)$ by factor level; the widths of the filled boxes represent the number of observations available by factor level, and the brackets indicate $95 \%$ confidence intervals.

significant variables for year, month, area, and recovery source (Table 4). Overall, about two CWT fish were recovered from the catch of 100 fishing trips. Variation in CWT recoveries by trip was greater among recovery sources than among years, areas, or months. Estimated recoveries by trip were highest among headhunters and lowest among creel clerks (Figure 2). Predictions from the GLM coefficients in Table 5 indicate that headhunters sampling catch from charterboat trips recovered on average 1.6 times the number of CWTs recovered when sampling catch from noncharter-boat trips, 7 times the number reported by charter-boat captains, and 11 times the number sampled by creel clerks from non-charter-boat catch. The CWT recoveries by trip increased from May to September, suggesting that fish moved from regions outside the study areas located in the east. Estimated recoveries by trip were highest in descending order in $\mathrm{MH} 2, \mathrm{MH} 3$, and MH5 (Figure 2), and relative levels did not coincide with those released by area, which were highest in MH1 (Table 6), suggesting net fish movement among areas. Annual recovery rates fluctuated between low levels at the beginning and at the end of the study period and high levels in 1994, 1995, and 1998 (Figure 2). Annual fluctuation in recoveries per trip did not match the trend in the total numbers of Chinook salmon stocked that was fairly constant between 1991 and 2000 (Table 1).

Analysis of interactions provided further information about seasonal movements among areas and eliminated concerns about differences in recovery efficiencies within recovery programs. Significant interaction between area and month $(P<0.04)$ indicated that CWT recoveries by trip did not vary in synchrony across statistical districts. The pattern observed was an

TABLE 5.-Coefficients for sources of recovery in a generalized linear model of Chinook salmon tag recovery rates. Coefficients are in logit-link scale and were estimated by means of a contrast treatment matrix and tags reported by charter boat captains as the reference level.

\begin{tabular}{lrrr}
\hline \multicolumn{1}{c}{ Coefficient } & Value & SE & $t$-value \\
\hline Charter self-reported & -5.770 & 0.141 & -40.8673 \\
Noncharter creel & -0.395 & 0.059 & -6.6570 \\
Charter headhunter & 1.884 & 0.128 & 14.7673 \\
Noncharter headhunter & 1.421 & 0.056 & 25.2789 \\
\hline
\end{tabular}


TABLE 6.- Release and recovery sites for coded-wire-tagged Chinook salmon released in Lake Huron for all years of the study and recovered from all sources (recreational fishing [pier, shore, and volunteer returns] and nonrecreational sources). The acronym ONT indicates Canadian districts $\mathrm{OH}-1$ to $\mathrm{OH}-5$ in Figure 1: "Lake Michigan" includes Michigan and Wisconsin waters.

\begin{tabular}{lrrrrrrr}
\hline & \multicolumn{7}{c}{ Release site } \\
\cline { 2 - 8 } Recovery site & MH1 & MH3 & MH4 & MH5 & MH6 & ONT & Total \\
\hline MH1 & 3,160 & 293 & 34 & 88 & 15 & 64 & 3,654 \\
MH2 & 619 & 404 & 24 & 106 & 9 & 121 & 1,283 \\
MH3 & 423 & 1,597 & 54 & 162 & 12 & 63 & 2,311 \\
MH4 & 181 & 244 & 107 & 110 & 16 & 44 & 702 \\
MH5 & 172 & 202 & 21 & 678 & 16 & 36 & 1,125 \\
MH6 & 165 & 197 & 30 & 149 & 28 & 59 & 628 \\
Ontario & 67 & 48 & 0 & 10 & 0 & - & 125 \\
Lake Michigan & 462 & 100 & 15 & 25 & 6 & 2 & 610 \\
Total & 5,250 & 3,085 & 285 & 1,328 & 102 & 389 & 10,438 \\
\hline
\end{tabular}

increase in recoveries by trip from south (MH6) to north (MH1) as the season progressed from May to August (Figure 3), suggesting that fish moved in a northerly direction during those months. In September and October, the pattern of CWT recovery rates remained similar among statistical districts; recovery levels were fairly uniform in statistical districts MH5 to MH1 and lower in MH6. Interactions between recovery source, area, and year were not significant, indicating that there were no differences in recovery efficiencies between personnel within recovery sources operating in different areas or years. The interaction between recovery source and month was significant and was probably caused by small sample sizes for particular source and month combinations, and it was not investigated further.
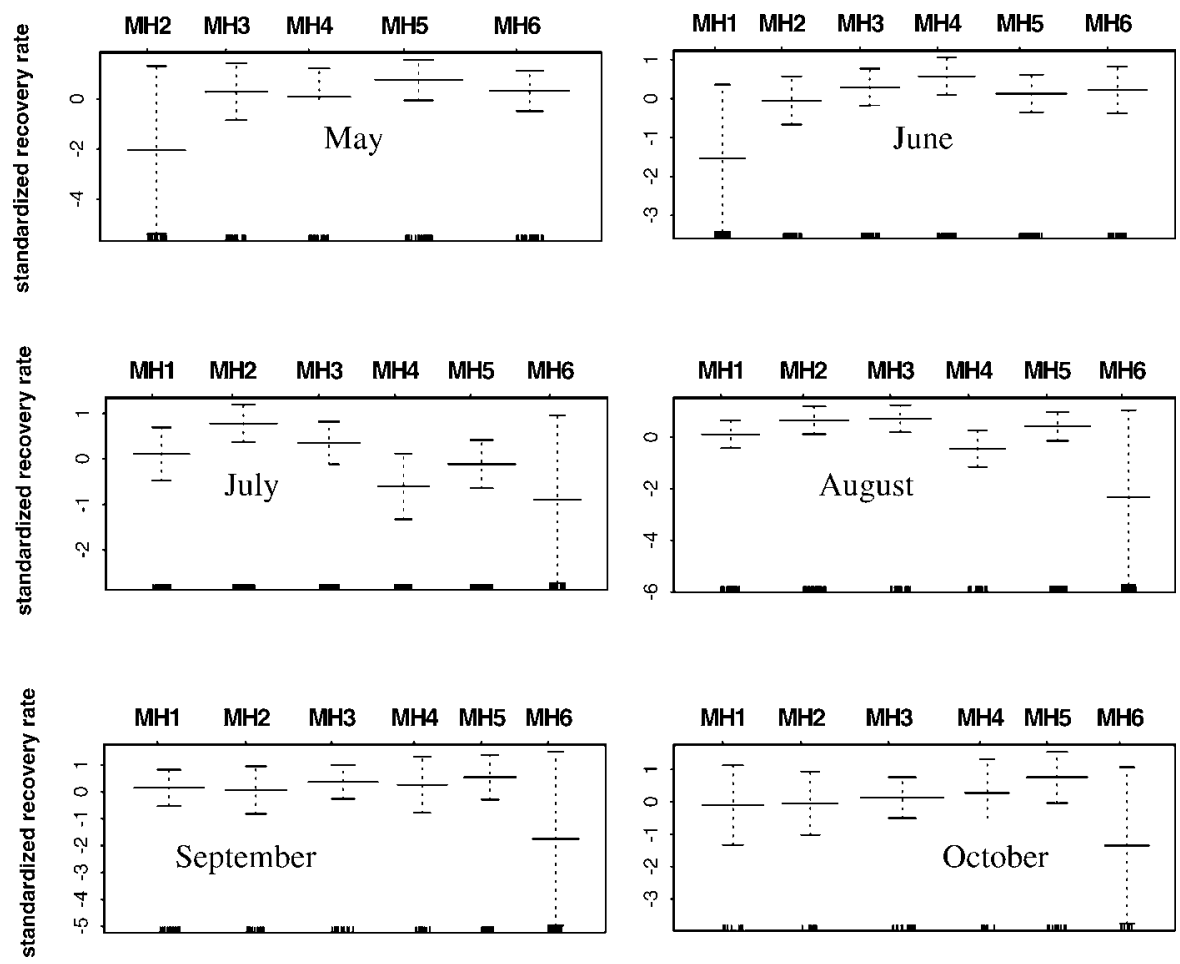

FIGURE 3.-Effects by month from generalized linear models of recovery rates of coded-wire-tagged Chinook salmon released in U.S. waters of Lake Huron from 1993 to 2000. The models also included year and source of recovery as predictors. Statistical district MH1 was not included in the May model because no recoveries were made. See Figure 2 for additional information. 

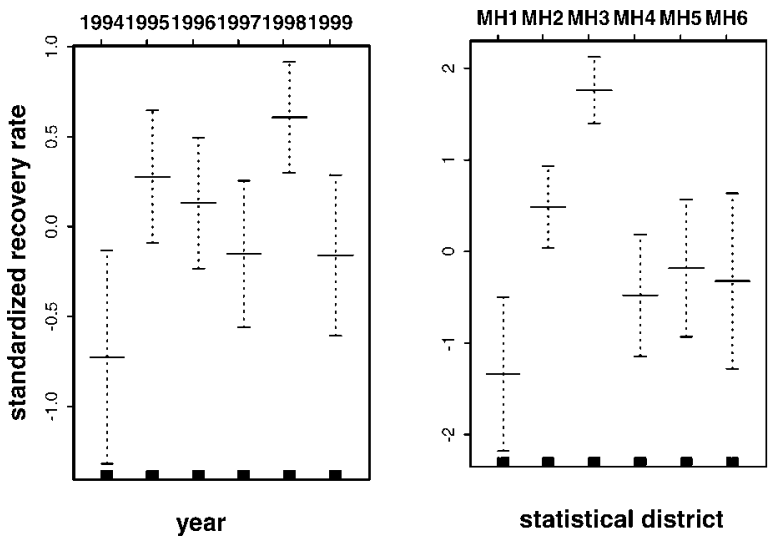

$\begin{array}{llllll}5 & 6 & 7 & 8 & 9 & 10\end{array}$

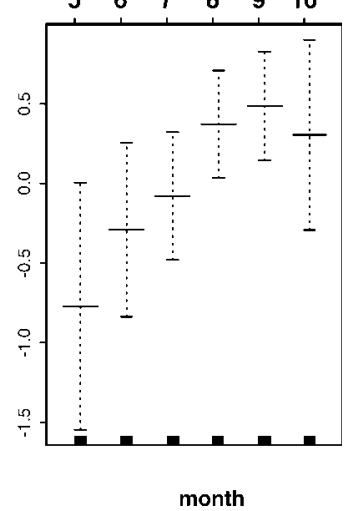

FIGURE 4.-Effects of year, statistical district, and month of recovery from generalized linear models of tagged Chinook salmon recoveries, by trips, from fish released in statistical district MH3 and caught by recreational fisheries from 1994 to 1999. See Figure 2 for additional information.

\section{GLM of Marked Fish Released in MH3 and Recovered from Recreational Fisheries}

Recoveries by trip were highest in the area of release; nevertheless, marked fish released in MH3 were recovered in all areas, indicating movement from the release areas to other areas (Figure 4). Recovery levels in all areas increased from May to August, suggesting that Chinook salmon made seasonal movements into nearshore waters (Figure 4). Further, significant monthly variation in CWT distributions indicated seasonal latitudinal movement. Interactions between month and area were significant and convey a pattern similar to that of the previous analysis of recoveries from all release areas of an increase in recoveries by trip from the south toward the north as the season progressed.

Maps of the GLM-standardized CWT distribution indicate increasing densities of Chinook salmon in northern areas from May to August paired with decreasing densities in the south (Figure 5). The distribution by month suggests westward and northward movements at the beginning of the season. Except for May, highest CWT fish concentrations occurred in MH3, and except in MH3, lowest levels were during October, suggesting that despite seasonal movements most fish remained in, or returned to, the release area where they concentrated to spawn.

Qualitative Analysis of Fish Released in U.S. and Canadian Waters and Recovered from All Recovery Sources

About 400 fish released in Canadian waters were recovered in U.S. waters in statistical districts MH1 to MH6, and more than 100 fish released in U.S. waters were recovered in Canada (Table 5). The Canadian tagged fish were recovered in U.S. waters in increasing numbers from April to July, then in decreasing numbers through October. Most of the fish tagged in the United States and recovered in Canada were found in November and April. Also, 610 CWT Chinook salmon released in Lake Huron, mostly in MH1 (Figure 1), were recovered in Lake Michigan (Table 5).

\section{Discussion}

Our results showed that recoveries by trip of CWT Chinook salmon in the Lake Huron recreational fisheries varied significantly among recovery sources and that this variation was larger than the fluctuations in time and space. The magnitude of the variation indicates that population studies based on unadjusted tag recoveries combined from several sources will be biased without accounting for differences in efficiency of recovery source.

Differences were found between fisheries and among recovery programs. The GLM coefficients derived in this study can be used to correct for this problem. The GLM coefficients for headhunters, who sampled charter and noncharter catch, indicate that charter-boat trips were likely to catch twice as many Chinook salmon per trip than non-charter-boat trips. Higher catches per trip occurred in charter operations because the numbers of anglers per boat were, on average, double those in noncharter operations, trips tended to be longer, the number of rods per angler was higher, and charter-boat captains had greater experience in catching fish than noncharter anglers. Differences were considerable in CWT recoveries by trip among recovery programs, particularly for headhunters who recovered tagged fish more efficiently than creel clerks and charter-boat captains. It is not surprising that headhunters were most efficient in recovering tags because the program was specifically implemented to 

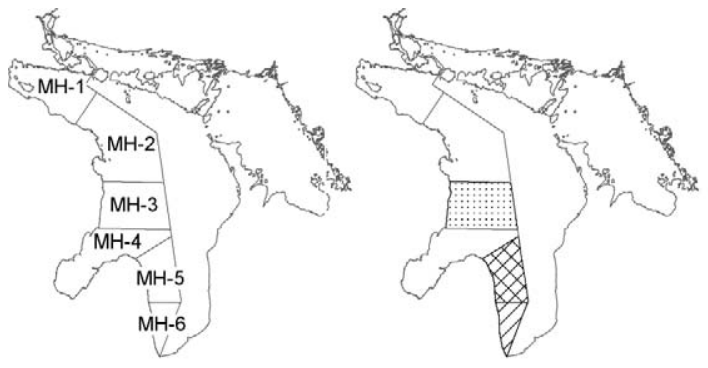

May

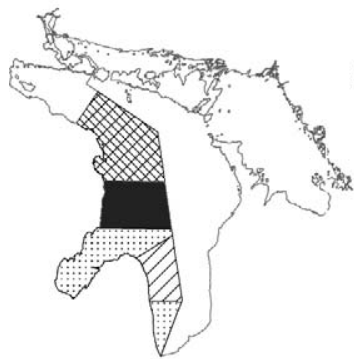

August

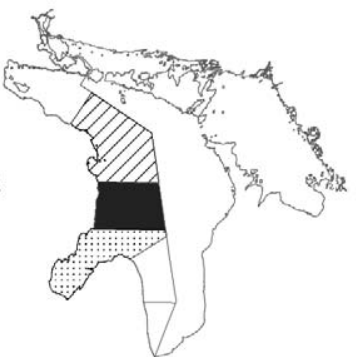

September

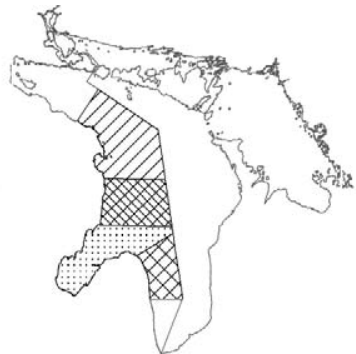

June

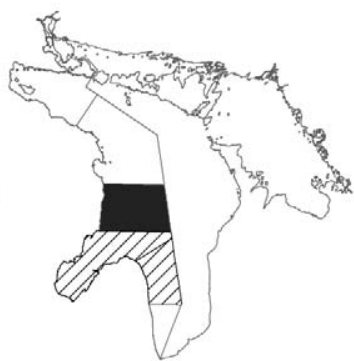

October

FIGURE 5.-Generalized linear model predictions of the monthly distribution of coded-wire-tagged Chinook salmon based on standardized recoveries, by trip, of fish released in statistical district MH3 and recovered in U.S. waters of Lake Huron from 1994 to 1999.

sample CWT fish; nevertheless, the magnitude of the difference was previously unknown. Charter captain recovery rates were similar to those reported by creel clerks sampling noncharter catch despite higher catch rates in charter fisheries. Since creel clerks do not collect tags and heads in every interview, this suggests that captains did not report all CWT Chinook salmon present in their catch. Charter captains are required to declare catch but not to collect CWT fish.

Our findings of Chinook salmon movements in Lake Huron are consistent with previous reports in Lake Michigan suggesting high mobility and seasonal migrations (Keller et al. 1990; Elliott 1993; Benjamin and Bence 2003). Despite high mobility, the highest number of recoveries occurred in the stocking area, indicating that the stocking location determines fish distribution during most of the fishing season. Results indicate that Chinook salmon released in U.S. waters of Lake Huron undergo substantial movements along coastal areas of western Lake Huron and between U.S. and Canadian waters. From our GLM results we infer that fish stocked in Michigan waters of Lake Huron moved into southwestern areas from the deeper waters to the east and continued to move west and also toward the north during summer. We presume that immature fish moved offshore eastward to deeper habitats in the fall.
Results on longitudinal seasonal movements were further supported by high numbers of CWT fish released in Michigan waters that were found in Canadian waters and vice versa. Currently, a large fraction of Chinook salmon in Lake Huron are wild born and the majority of the natural reproduction is thought to occur in Ontario waters (Bence et al., in press). If the movements of Chinook salmon stocked in Canada are representative of movement patterns of the wild-born fish from Canadian tributaries, it appears likely that large numbers of Chinook salmon inhabit Michigan waters in early spring, but many migrate to the east side of the lake after July. Most of the fish tagged in the United States and recovered in Canada were found in November and April, as expected if they overwinter in deeper eastern waters of Lake Huron. Nevertheless, these recoveries were primarily from commercial gill-net catch and could be affected by seasonal regulations and peak fishing periods in Canadian waters. Regardless of this potential source of bias, the finding of CWT fish in Canadian waters that were marked along the west coast of Lake Huron shows that fish moved east and were present in waters in the east during fall.

There are no previous studies with which to compare our findings on Chinook salmon seasonal distribution in Lake Huron, but our results are consistent with observations on latitudinal seasonal changes in Chi- 
nook salmon distribution made by Diana (1990). Diana (1990) attempted to collect sufficient Chinook salmon specimens for diet analysis along the western shore of Lake Huron and found that Chinook salmon were available only from near Port Huron in the south during May and from northern areas in July. Diana (1990) concluded that salmon migrated in a northerly direction in western Lake Huron during summer. We propose that Chinook salmon stocked along the western shore of Lake Huron overwinter in deep waters of Lake Huron and return toward the west coast in summer (where some fish return to stocking rivers to spawn in the fall).

An alternative, but unlikely, explanation for the spatial and temporal distributions of CWT recovery rates in the recreational fisheries is that the catchability of Chinook salmon varies owing to shifts in fish or angler behavior. Although Chinook salmon are caught during trips when anglers target salmonines, and higher catch rates are experienced in trips where Chinook salmon are targeted, they are by far the preferred species, and angler behavior should not bias the patterns observed in CWT recovery rates. Having currently unavailable information on the target species from charter-boat operations would be helpful in further addressing the issue. Increases in catch rates with the advancement of the fishing season also can be due to warming conditions that may increase vulnerability to angling by increased fish consumption rates. There is no information to elaborate further on these points.

Studies of Chinook salmon populations in the Pacific Northwest suggest that ocean movements patterns are heritable (Myers et al. 2005), and this may influence the movements of Lake Huron stocks. Differences in migration patterns of Pacific salmonids are driven by life history types and geography. Oceantype Chinook salmon emigrate from streams at $5-8 \mathrm{~cm}$ and remain in coastal waters throughout their ocean life, whereas stream-type fish spend one or more years in the streams before entering the ocean at 9-12 cm and then migrate far offshore (Healey and Groot 1987). After ocean entry, ocean-type Chinook salmon populations from rivers south of Cape Blanco, Oregon, move primarily southward, while populations north of Cape Blanco move north (Myers et al. 2005). The source of eggs for Chinook salmon introduced in Lake Huron came from the Green River located north of Cape Blanco (Weeder et al. 2005), and this population shows distinct northward movement patterns during spring and summer, as we found for Lake Huron salmon.

The movements of Chinook salmon and the temporal distributions of other salmonines in the Great
Lakes have been associated with relative abundance of prey (Elliott 1993; Höök et al. 2004). In the Pacific Northwest, historic ocean distributions of salmon correspond with areas of known high productivity (Pearcy 1992). In Lake Michigan, Höök et al. (2004) found that the catch per unit effort (CPUE) of steelhead Oncorhynchus mykiss was often highest in the western portion of the Lake Michigan area, where Brandt et al. (1991) reported high densities of alewives, a preferred prey of steelhead. Rainbow smelt and alewives are the major components of Chinook salmon and other salmonine diets in Lake Huron (Diana 1990; Dobiesz et al. 2003). Since 2003, drastic declines in alewife biomass in Lake Huron have coincided with increased movements of CWT Chinook salmon from Lake Huron to Lake Michigan (Johnson et al., in press). In Lake Huron, as elsewhere in the Great Lakes, alewives undergo annual migrations from deep wintering areas toward shallow waters during spring to spawn as water temperatures warm, and then they return to deeper waters in fall (Brown 1972; Argyle 1982; Brandt et al. 1991). Thus, inshore-offshore movements of Chinook salmon as revealed by our study seem to follow alewife seasonal migrations.

The spatial and temporal distributions of Great Lakes and Pacific salmonines also are influenced by temperature (Haynes and Keleher 1986; Haynes et al. 1986; Nettles et al. 1987; Olson et al. 1988; Höök et al. 2004). The thermal preference of Chinook salmon ranges from $10^{\circ} \mathrm{C}$ to $12^{\circ} \mathrm{C}$ (Stewart and Ibarra 1991). In Lake Ontario, Olson et al. (1988) found Chinook salmon occupying waters averaging $14.4^{\circ} \mathrm{C}$ around the thermocline during summer. Estimates of thermal histories of Chinook salmon in Lake Ontario obtained from stable isotope analysis of otoliths indicate salmon inhabit epilimnetic temperatures of $19-20^{\circ} \mathrm{C}$ during summer (Wurster et al. 2005), well above their thermal preference but coincident with that of alewife prey. Data from thermal tag recoveries (Walker et al. 2000) of Chinook salmon off Oregon and California indicate that fish spent most $(52 \%)$ of their time in water temperatures of $9-12^{\circ} \mathrm{C}$ during fall, which comprised only $25-37 \%$ of the available thermal habitat (Hinke et al. 2005). In Lake Huron, water temperatures near 10$12^{\circ} \mathrm{C}$ are more common in the southeast during spring and in nearshore areas in the west by summer. Recent reports of thermal tag recoveries in the Great Lakes (Ray Argyle, USGS, Biological Resources Division, unpublished data) suggest that Chinook salmon in Lake Huron seek the warmest waters available during winter, which were often at great depths and located in Canadian waters. Thus, spatial and seasonal variation in both temperature and distribution of prey are 
consistent with movement patterns of Chinook salmon found in this study.

Our findings that fish stocked at various sites move across management units and between countries are relevant for management and suggest that management of the Chinook salmon fishery must be coordinated among agency jurisdictions. It appears that prey distribution or environmental conditions in the lake are as important as location of stocking in mediating adult distribution during the fishing season, although in fall mature Chinook salmon tended to be concentrated in their areas of stocking. Thus, stocking appears to provide fishing opportunities in areas of high fishing pressure, even where reproduction is lacking. These results are relevant for stocking allocation as managers are using movement patterns along with other indices (catch rates, growth) as guidelines for reducing salmon stocking in both Lake Huron and Lake Michigan (Johnson et al., in press). Further, our results support the hypothesis of the existence of a single Chinook salmon stock in the main basin of Lake Huron, which is the basis for management that treats the stock as one unit. Nevertheless, further work is needed to determine movements, gene flow, and population structure of wild salmon.

Although our study objectives did not include investigating the contribution of natural reproduction to the Chinook population in Lake Huron, our results can provide relevant information. Our finding that recovery rates declined during later study years and that the decline did not match corresponding CWT fish or total stocking numbers in previous years suggests increasing Chinook salmon natural reproduction in Lake Huron, which is consistent with the findings of Bence et al. (in press). Alternatively, the decline can be the result from movement of CWT fish released in Lake Huron to Lake Michigan (as documented in this study) due to declining prey stocks, and to higher mortality rates of Chinook salmon. Mortality rates of Chinook salmon, nevertheless, have remained relatively stable despite declines in prey stocks (Dobiesz et al. 2003).

One of the aims of our study was to evaluate the use of recovery data of CWT Chinook salmon for movement studies, and the analysis provided valuable insights for improving future tagging studies in the Great Lakes and elsewhere. We believe that every effort should be made to improve the value of data available on marked fish recoveries for investigating movement or other aspects of populations that require accounting for recovery efforts. We recommend the following: (1) identifying trips sampled by recovery programs for tagged fish to greatly improve the precision of recovery rate estimates, which should add no cost to surveys or burden normal workloads; (2) improving and standardizing the precision of the geographic reference of various fishing operations to allow a better spatial match between recovery effort and the capture location of marked fish; (3) integrating multiple tag recovery and fishery monitoring programs using similar protocols to provide data with appropriate spatial-temporal coverage for movement studies; (4) documenting special educational programs and rewards to increase tag recovery rates to identify potential sources of bias for movement analysis; (5) coordinating surveys with all relevant agencies to perform areawide assessments of tagged fish; and (6) maintaining a dedicated, standardized effort to recover tagged fish to provide adequate sample sizes. In the Great Lakes, agencies are currently considering coordinated expansion of the current Chinook salmon tagging program. It is therefore timely to equate efforts in marking strategies with those of recovering tagged fish.

\section{Acknowledgments}

Funding for this study was provided through a grant from the U.S. Environmental Protection Agency. Additional funding for this study was provided through a grant from Federal Aid in Sport Fish Restoration (F80-R) and from the Game and Fish Protection Fund (Michigan Department of Natural Resources). We acknowledge the significant contributions of Paul Gelderblom, Pat O’Neill, Tim Smigielski, Sarah Thayer, and Donna Wesander in sample processing, data entry, and management.

\section{References}

Argyle, R. L. 1982. Alewives and rainbow smelt in Lake Huron: midwater and bottom aggregations and estimates of standing stocks. Transactions of the American Fisheries Society 111:267-285.

Becker, R. A., J. M. Chambers, and A. R. Wilks. 1988. The new $S$ language: a programming environment for data analysis and graphics. Wadsworth \& Brooks/Cole Advanced Books \& Software, Pacific Grove, California.

Bence, J. R., M. Ebener, D. Gonder, J. X. He, J. E. Johnson, L. Mohr, J. Morse, J. Schaeffer, D. Reid, S. Riley, A. Woldt, and R. Younget. In press. Offshore predator community. In J. R. Bence, editor. The state of Lake Huron in 2004. Great Lakes Fishery Commission Special Publication, Ann Arbor, Michigan.

Benjamin, D. M., and J. R. Bence. 2003. Spatial and temporal changes in the Lake Michigan Chinook salmon fishery, 1985-1996. Michigan Department of Natural Resources, Fisheries Research Report 2065, Ann Arbor.

Brandt, S. B., D. M. Mason, E. V. Patrick, R. L. Argyle, L. Wells, and D. J. Stewart. 1991. Acoustic measures of the abundance and size of pelagic planktivores in Lake Michigan. Canadian Journal of Fisheries and Aquatic Sciences 48:894-908.

Brown, E. H. 1972. Population biology of alewives, Alosa 
pseudoharengus, in Lake Michigan, 1949-70. Journal of the Fisheries Research Board of Canada 29:477-500.

Diana, J. S. 1990. Food habits of angler-caught salmonines in western Lake Huron. Journal of Great Lakes Research 16:271-278.

Dobiesz, N. E., D. A. McLeish, R. L. Eshenroder, J. R. Bence, L. C. Mohr, M. P. Ebener, T. F. Nalepa, A. P. Woldt, J. E. Johnson, R. L. Argyle, and J. C. Makarewicz. 2003. Ecology of the Lake Huron fish community, 1970-1999. Canadian Journal of Fisheries and Aquatic Sciences 62:1432-1451.

Elliott, R. F. 1993. Feeding habits of Chinook salmon in eastern Lake Michigan. Master's thesis. Michigan State University, East Lansing.

Great Lakes Fishery Commission. 2006. Great Lakes fish stocking database. Available: www.glfc.org/fishstocking/ index.htm. (April 2006).

Hale, R. S., and J. H. Gray. 1998. Retention and detection of coded wire tags and elastomer tags in trout. North American Journal of Fisheries Management 18:197-201.

Haynes, J. M., and C. J. Keleher. 1986. Movements of Pacific salmon in Lake Ontario in spring and summer: evidence for wide dispersal. Journal of Freshwater Ecology 3:289297.

Haynes, J. M., D. C. Nettles, K. M. Parnell, M. P. Voiland, R. A. Olson, and J. D. Winter. 1986. Movements of rainbow steelhead trout (Salmo gairdneri) in Lake Ontario and a hypothesis for the influence of spring thermal structure. Journal of Great Lakes Research 12:304-313.

Healey, M. C., and C. Groot. 1987. Marine migration and orientation of ocean-type Chinook and sockeye salmon. Pages 298-312 in M. J. Dadswell, R. J. Klauda, C. M. Moffitt, R. L. Saunders, R. A. Rulifson, and J. E. Cooper, editors. Common strategies of anadromous and catadromous fishes. American Fisheries Society, Symposium 1, Bethesda, Maryland.

Hilborn, R. 1990. Determination of fish movement patterns from tag recoveries using maximum likelihood estimators. Canadian Journal of Fisheries and Aquatic Sciences 47:635-643.

Hinke, J. T., G. M. Watters, G. W. Boehlert, and P. Zedonis. 2005. Ocean habitat use in autumn by Chinook salmon in coastal waters of Oregon and California. Marine Ecology Progress Series 285:181-192.

Höök, T. O., E. S. Rutherford, S. J. Brines, D. J. Schwab, and J. McCormick. 2004. Relationship between surface water temperature and steelhead distributions in Lake Michigan. North American Journal of Fisheries Management 24:211-221.

Johnson, J. E., D. Gonder, and L. C. Mohr. In press. Chinook salmon. In J. R. Bence, editor. The state of Lake Huron in 2004. Great Lakes Fishery Commission, Special Publication, Ann Arbor, Michigan.

Keller, M., K. D. Smith, and R. W. Rybicki, editors. 1990. Review of salmon and trout management in Lake Michigan. Michigan Department of Natural Resources, Fisheries Special Report 14, Charlevoix.

Kocik, J. E., and M. L Jones. 1999. Pacific salmonines in the Great Lakes basin. Pages 455-488 in W. W. Taylor and C. P. Ferreri, editors. Great Lakes fisheries policy and management: a binational perspective. Michigan State University Press, East Lansing.
Lake Huron Technical Committee and Lake Michigan Salmonid Working Group. 2005. Analysis of the Chinook salmon populations of Lakes Huron and Michigan, 1985-2004. Michigan Department of Natural Resources, Report of the 2005 Great Lakes Fishery Commission Upper Lake Meetings, Lansing.

McCullagh, P., and J. A. Nelder. 1989. Generalized linear models. Chapman and Hall, London.

Myers, J. M., R. G. Kope, G. J. Bryant, D. Teel, L. J. Lierheimer, T. C. Wainwright, W. S. Grant, F. W. Waknitz, K. Neely, S. T. Lindley, and R. S. Waples. 2005. Status review of Chinook salmon from Washington, Idaho, Oregon, and California. NOAA Technical Memorandum NMFS-NWFSC-35.

Nettles, D. C., J. M. Haynes, R. A. Olson, and J. D. Winter. 1987. Seasonal movements of brown trout (Salmo trutta) in south-central Lake Ontario. Journal of Great Lakes Research 13:168-177.

Olson, R. A., J. D. Winter, D. C. Nettles, and J. M. Haynes. 1988. Resource partitioning in summer by salmonids in south-central Lake Ontario. Transactions of the American Fisheries Society 117:552-559.

Pearcy, W. G. 1992. Ocean ecology of North Pacific salmonids. University of Washington Press, Seattle.

Schmalz, P. J., M. J. Hansen, M. E. Holey, P. C. McKee, and M. Toneys. 2002. Lake trout movements in northwestern Lake Michigan. North American Journal of Fisheries Management 22:737-749.

Smith, S. J. 1990. Use of statistical models for the estimation of abundance from groundfish trawl surveys. Canadian Journal of Fisheries and Aquatic Sciences 47:894-903.

Stewart, D. J., and M. Ibarra. 1991. Predation and production by salmonine fishes in Lake Michigan, 1978-1988. Canadian Journal of Fisheries and Aquatic Sciences 48:909-922.

Tody, W. H., and H. A. Tanner. 1966. Coho salmon for the Great Lakes. Michigan Department of Natural Resources, Fish Management Report 1, Lansing.

Walker, R. V., K. W. Myers, N. D. Davis, K. Y. Aydin, K. D. Friedland, H. R. Carlson, G. W. Boehlert, S. Urawa, Y. Ueno, and G. Amna. 2000. Diurnal variation in thermal environment experienced by salmonids in the North Pacific as indicated by data storage tags. Fisheries Oceanography 9:171-186.

Weeder, J. A., A. R. Marshall, and J. M. Epifanio. 2005. An assessment of population genetic variation in Chinook salmon from seven Michigan rivers 30 years after introduction. North American Journal of Fisheries Management 25:861-875.

Whelan, G. E., and J. E. Johnson. 2004. Successes and failures of large-scale ecosystem manipulation using hatchery production: the upper Great Lakes experience. Pages 332 in M. J. Nickum, P. M. Mazik, J. G. Nickum, and D. D. MacKinlay, editors. Propagated fish in resource management. American Fisheries Society, Symposium 44, Bethesda, Maryland.

Wurster, C. M., W. P. Patterson, D. J. Stewart, J. N. Bowlby, and T. J. Stewart. 2005. Thermal histories, stress, and metabolic rates of Chinook salmon (Oncorhynchus tshawytscha) in Lake Ontario: evidence from intra-otolith stable isotope analyses. Canadian Journal of Fisheries and Aquatic Sciences 62:700-713. 